Original Article

\title{
ANTIHEPATOTOXIC POTENTIALITY OF 2-3-6 TRIMETHYLOCT-6-ENAL AGAINST PARACETAMOL INDUCED LIVER DYSFUNCTION
}

\author{
SUPARNA DATTA*, MANABENDRA DUTTA CHOUDHURY \\ Ethnobotany and Medicinal Plant Research Laboratory, Department of Life Science and Bioinformatics, Assam University, Silchar, Assam, India \\ Email: suparnares@gmail.com
}

Received: 10 Apr 2017 Revised and Accepted: 13 Jul 2017

\section{ABSTRACT}

Objective: We investigated the liver protective activity of 2-3-6 trimethyloct-6-enal from the methanol extract of Pajanelia longifolia (Willd.) K. Schuman. The liver protective activity of 2,3,6 trimethyloct-6-enal was evaluated against paracetamol ( $2 \mathrm{mg} / \mathrm{kg}$ body weight per orally) induced liver toxicity in swiss albino mice.

Methods: Considering the Spectral data (IR spectrum, ${ }^{1} \mathrm{HNMR}$ spectrum and ${ }^{13} \mathrm{C}$ NMR spectrum) the predictable structure of $2,3,6$ trimethyloct-6enal was elucidated. To study the liver protective activity of the compound, Swiss albino mice of either sex were divided into six groups and treated for $5 \mathrm{~d}$. Group I and II served as normal and toxic control, Group III were treated with Silymarin as a standard drug (50 mg/kg), and Group IV to VI was treated with 2-3-6 trimethyloct-6-enal at the dose of $50 \mathrm{mg} / \mathrm{kg}, 150 \mathrm{mg} / \mathrm{kg}$ and $250 \mathrm{mg} / \mathrm{kg}$ b.w. p. o. respectively. The liver protective activity of the compound was measured on biochemical parameters such as aspertate amino transferase (AST), alanine amino transferase (ALT), alkaline phosphatase (ALP), total bilirubin (TB), triglycerides (TGL), total cholesterol (TC) and protein. Further antioxidant activity of the compound was also measured on antioxidant enzymatic and non-enzymatic levels such as reduced glutathione (GSH), lipid peroxidation (LPO), superoxide dismutase (SOD), catalase (CAT) and glutathione peroxidase (GPx)).

Results: The study revealed that the compound has protective activity at the dose of 50, 150 and $250 \mathrm{mg} / \mathrm{kg}$ b.w. p. o. against paracetamol induced toxicity. In some biochemical parameters such as aspartate amino transferase and bilirubin, the compound has showed better result at a dose of 150 $\mathrm{mg} / \mathrm{kg}$ compared to standard drug silymarin (value of aspartate amino transferase (compound) $=71.10 \pm 0.12$, (toxic) $=173.43 \pm 1.21$, (silymarin) $=79.86 \pm 0.02$ and total bilirubin (compound) $=1.04 \pm 0.11$ ), (toxic) $=2.69 \pm 0.02$, (silymarin) $==1.11 \pm 0.01$. The findings were also confirmed by histopathological observations.

Conclusion: 2,3,6 trimethyloct-6-enal from Pajanelia longifolia may be considered as a potent liver protective agent.

Keywords: 2,3,6 trimethyloct-6-enal, Liver protective activity, Paracetamol, Histopathological observations, Pajanelia longifolia (Willd.) K. Schuman (C) 2017 The Authors. Published by Innovare Academic Sciences Pvt Ltd. This is an open access article under the CC BY license (http://creativecommons.org/licenses/by/4.0/) DOI: http://dx.doi.org/10.22159/ijpps.2017v9i9.19075

\section{INTRODUCTION}

Herbs plays a significant role as health beneficial food and as source material for drug development to treat a wide variety of clinical diseases. Liver, the largest organ of the body, plays a key role in metabolism. It's highly specialised tissues control high-volume biochemical reactions and continue the vital functions of the body [1-2]. Because of its diverse functional roles, the liver is a sensitive organ. Acute and chronic liver diseases interfere with the liver functions and substantially cause damage of it. Paracetamol is widely used as a hepatotoxin in hepatoprotective studies causing toxicity in an animal model. Herbal medicines have attracted attention to treate liver diseases because of its less side effects and cost efficiency. Silymarin is widely used as a standard hepatoprotective drug for the study of the hepatoprotective activity of natural product [3]. Numerous medicinal plants and their crude extracts have been reported for their hepatoprotective and antioxidant activity. In spite of great progress in modern medicine, there are hardly any suitable drug which has liver protective efficacy in all respect. To withstand this problem the potential hepatoprotective and antioxidant substance is tested in in vivo [4-6].

Pajanelia longifolia (Willd.) K. Schuman, belongs to the family Bignoniaceae, The bark of the plant is widely used in Southern Assam as a folkloric medicine for curing jaundice [7]. It is a terrestrial plant, medium in size, found both as wild and less cultivated. However, from the literature survey, it was found that there are less scientific studies have been carried out regarding the hepatoprotective activity of the plant. Therefore, it was our interest to investigate the hepatoprotective as well as the antioxidant activity of the isolated compound from the stem bark of mentioned plant against paracetamol induced hepatotoxicity in albino mice.

\section{MATERIALS AND METHODS}

\section{Plant material}

Pajanelia longifolia (Willd.) K. Schuman was collected from Cachar district of Southern Assam part of North East India. The plant was identified at the Assam University Herbarium, Silchar and a voucher specimen (H-17) was deposited for future reference. The air-dried and powdered bark (500 gm) was defatted at room temperature with n-hexane followed by extraction with methanol $(1500 \mathrm{ml})$. Qualitative phytochemical screening of the crude extracts was performed following the method suggested by Siddiqui and Ali [8].

\section{Methodology for bioactivity analysis}

\section{Animal}

Swiss albino mice (24-26 g) of either sex were obtained from animal house of Assam University. The animals were housed individually in acrylic cages and maintained under controlled conditions of temperature $\left(24 \pm 2{ }^{\circ} \mathrm{C}\right)$ and relative humidity $(30-70 \%)$ with a $12: 12$ light: dark cycle throughout the period of the experiment. They were provided with standard laboratory diet ad libitum. The animal studies were approved Institutional Animal Ethics Committee.

\section{Chemicals}

Paracetamol (Apex Laboratories Limited), Silymarin received from Ranbaxy India Ltd. As gift sample. All other chemicals were of analytical grade and purchased from Merck India Ltd., Mumbai, India.

\section{Paracetamol induced hepatotoxicity}

The hepatic injury was created by inducing paracetamol $(2 \mathrm{mg} / \mathrm{kg}$ body weight per orally) according to the literature [4] with slight 
modifications. On the basis of acute toxicity study the dose concentration of 2-3-6 trimethyloct-6-enal were selected as 50 $\mathrm{mg} / \mathrm{kg}, 150 \mathrm{mg} / \mathrm{kg}$ and $250 \mathrm{mg} / \mathrm{kg}$ b.w. p. o. Animals were divided into six groups with six animals each as follows, Group I: normal control, received liquid paraffin $(1 \mathrm{ml} / \mathrm{kg}$ b.w. p. o.) for $5 \mathrm{~d}$. Group II: negative control, received liquid paraffin ( $1 \mathrm{ml} / \mathrm{kg}$ b.w. p. o.) and the single dose of paracetamol ( $2 \mathrm{mg} / \mathrm{kg}$ ) b.w. p. o. once daily for $5 \mathrm{~d}$. Group III: positive control treated with Silymarin $(50 \mathrm{mg} / \mathrm{kg}$ b.w. p. o.) and Group IV,V, VI treated with $(50 \mathrm{mg} / \mathrm{kg}, 150 \mathrm{mg} / \mathrm{kg}$ and 250 $\mathrm{mg} / \mathrm{kg}$ b.w. p. o respectively for $5 \mathrm{~d}$. Groups III-VI animals were administered simultaneously Paracetamol ( $2 \mathrm{mg} / \mathrm{kg}$ b.w. p. o.) with vehicles once daily for $5 \mathrm{~d}$ after $30 \mathrm{~min}$. of administration of the doses. Animals were sacrificed $24 \mathrm{~h}$ after the last treatment i.e. on $6^{\text {th-day }}$ blood samples were collected and the animals were sacrificed to assess the liver function and histological changes.

\section{Biochemical assay}

\section{Measurement of biochemical parameters}

Serum of Swiss albino mice was used for biochemical analysis, such as aspartate amino transferase (AST), alanine amino transferase (ALT) levels were measured as per the method suggested by Reitman and Frankle [9]. The total bilirubin (TB) content was measured as per the method suggested by Malloy and Evelyn [10] and alkaline phosphatase (ALP) level was measured as per the method of Sood [11], protein [12] triglycerides (TGL) and total cholesterol (TC) levels were assessed by kit methods as per instructions provided by the company Merck India Ltd.

\section{Preparation of liver homogenate}

Liver samples from the sacrificed mice was quickly removed and pursued with ice-cold saline. A portion of the liver was homogenized in chilled sodium phosphate buffer $(0.1 \mathrm{M}, \mathrm{pH} 7.4)$ using a Potter Eleven homogenizer. The homogenate obtained was centrifuged in a cooling centrifuge at $12,000 \mathrm{xg}$ for $30 \mathrm{~min}$ at $4{ }^{\circ} \mathrm{C}$ to separate the nuclear debris. The supernatant was collected and used for the subsequent assays [13].

Analysis of antioxidant activity by measuring antioxidant enzymatic and non-enzymatic levels

\section{Catalase (CAT) assay}

Catalase assay was performed following the method based on the disappearance of $\mathrm{H}_{2} \mathrm{O}_{2}$ at $25{ }^{\circ} \mathrm{C}$ catalase [14] $5 \mu \mathrm{l}$ of diluted homogenate $(1: 40)$ was mixed with $720 \mu \mathrm{l}$ of $30 \mathrm{mmol} \mathrm{H}_{2} \mathrm{O}_{2}$ in 10 mmol potassium phosphate solution and the reaction was followed at $240 \mathrm{~nm}$. Decomposition of $\mathrm{H}_{2} \mathrm{O}_{2}$ by CAT contained follows a first order kinetics as $\mathrm{K}=2.3 / \mathrm{t} \log \mathrm{Ao} / \mathrm{A}$ where $\mathrm{K}$ is the first order rate constant, $t$ is the time for which the decrease of $\mathrm{H}_{2} \mathrm{O}_{2}$ due to CAT activity was measured for $15 \mathrm{~s}$ and Ao/A is the optical density at time 0 and at 15 s respectively.

\section{Superoxide dismutase (SOD) activity}

The reaction mixture consisted of $1.5 \mathrm{ml}$ phosphate buffer $(0.1 \mathrm{M}, \mathrm{pH}$ 7.4) $0.1 \mathrm{ml}$ NBT (2.25 mmol, $0.1 \mathrm{ml}$ tissue homogenate, $0.1 \mathrm{ml}$ sodium carbonate $(1.5 \mathrm{M}), 0.2 \mathrm{ml}$ methionine $(200 \mathrm{~mm}), 0.1 \mathrm{ml}$ EDTA ( $3 \mathrm{mmol}) 1 \mathrm{ml}$ distilled water and 0.1 riboflavin $(60 \mathrm{mmol})$ in the total volume of $3 \mathrm{ml}$. It was incubated in light for $60 \mathrm{~min}$ at room temperature. The rate of reaction was measured by recording changes in absorbance at $560 \mathrm{~nm}$ due to the formation of formazone, a reaction product of NBT [15].

\section{Glutathione peroxidase (GPx) assay}

$100 \mu \mathrm{l}$ of the tissue homogenate diluted in 1:100 was added to $800 \mu \mathrm{l}$ of a reaction mixture containing $50 \mathrm{mmol}$ potassium phosphate solution $\mathrm{pH} 7.0,1 \mathrm{mmol}$ EDTA, $1 \mathrm{mmol}$ sodium azide, $0.2 \mathrm{mmol}$ $\mathrm{NADPH}, 1 \mathrm{Unit} / \mathrm{ml}$ of GR and $1 \mathrm{mmol} \mathrm{GSH}$. The reaction mixture was incubated at room temperature for $5 \mathrm{~min}$ before addition of $32 \mu \mathrm{l}$ of $2.5 \mathrm{mmol} \mathrm{H}_{2} \mathrm{O}_{2}$ Solution for the initiation of the reaction and finally, absorbance at $340 \mathrm{~nm}$ was recorded for $3 \mathrm{~min}$ and the activity was calculated focussing on millimolar absorption coefficient for NADPH being 6.22. In the case of blank reactions homogenates were replaced by distilled water which was subtracted from each assay [14].

\section{Reduced glutathione (GSH) content}

$0.2 \mathrm{ml}$ of tissue homogenate was mixed with $1.8 \mathrm{ml}$ of EDTA solution. To this $3.0 \mathrm{ml}$ of precipitating reagent $(1.67 \mathrm{~g}$ of meta phosphoric acid, $0.2 \mathrm{~g}$ of EDTA disodium salt, $30 \mathrm{~g}$ sodium chloride in $1 \mathrm{~L}$ of distilled water) was added mixed thoroughly and kept for 5 min before centrifugation. $2.0 \mathrm{ml}$ of the filtrate, $4.0 \mathrm{ml}$ of $0.3 \mathrm{M}$ disodium hydrogen phosphate solution and $1.0 \mathrm{ml}$ of DTNB (5.5dithiobis-2-nitrobenzoic acid) reagent were added and absorbance was read at $412 \mathrm{~nm}$ [16].

\section{Lipid peroxidation (LPO) assay}

Determination of Hepatic TBARS which signifies the rate of lipid peroxidation was carried out by following the standard method [17]. Briefly, the tissue was homogenized in chilled $0.1 \mathrm{M}$ potassium chloride solution. The assay mixture contained $0.5 \mathrm{ml}$ of liver homogenate, $3 \mathrm{ml}$ of $1 \% \mathrm{H}_{3} \mathrm{PO}_{4}$ and $1 \mathrm{ml}$ of $0.6 \%$ TBA. The mixture was heated at $100{ }^{\circ} \mathrm{C}$ for $45 \mathrm{~min}$, the reaction mixture was then allowed to cool at room temperature and $3 \mathrm{ml}$ of $\mathrm{n}$-butanol was added to it and shaken vigorously so as to separate the butanolic phase, it was then subjected to centrifugation at $4000 \mathrm{xg}$ for $10 \mathrm{~min}$. and absorbance was determined at $535 \mathrm{~nm}$.

\section{Histopathological observation}

Liver tissues were fixed in 10\% formalin and were graded with ethanol. The paraffin embedded liver tissue was cut into thin sections, stained with Haematoxylin-Eosin dye and observed under a microscope (BX41, OLYMPUS) to note the changes in the liver tissue [18].

\section{Statistical analysis}

The data presented here were expressed as mean \pm SE. The results were analysed by one way ANOVA with Tukey-Kramer multiple comparisons test. The level of significance was accepted at $\mathrm{P}<0.001$, $\mathrm{P}<0.01$ and $\mathrm{P}<0.05$

\section{RESULTS}

\section{Preliminary phytochemical screening}

The preliminary phytochemical screening of acetone extract revealed the presence of secondary metabolites like-alkaloids, steroids, tannin, reducing sugar and flavonoids.

\section{The probable structure of the compound}

Considering spectral data the structure elucidation of the compound has reported in our previous study Datta and Choudhury (19).

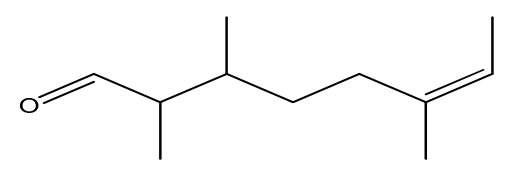

$$
\text { 2,3,6-trimethyloct-6-enal }
$$

Fig. 1: Structure of 2-3-6 trimethyloct-6-enal

\section{Bioactivity of 2-3-6 trimethyloct-6-enal}

\section{Measurement of Biochemical parameters}

Hepatotoxicity of mice with paracetamol induction significantly $(\mathrm{P}<0.001)$ altered the biochemical parameters when compared with control mice. Treatment with 2-3-6 trimethyloct-6-enal at $50 \mathrm{mg} / \mathrm{kg}$, $150 \mathrm{mg} / \mathrm{kg}$ and $250 \mathrm{mg} / \mathrm{kg}$ showed significant protective effect by decreasing the paracetamol induced elevated levels of serum biochemical parameters $(\mathrm{P}<0.001, \mathrm{P}<0.01, \mathrm{P}<0.05)$ and by increasing the decreased levels of Protein and triglycerides $(\mathrm{P}<0.001, \mathrm{P}<0.01$ and $\mathrm{P}<0.05)$. The protective efficacy showed by the compound was similar to that of the Standard drug, Silymarin. In some biochemical parameters such as aspartate amino transferase (AST) and bilirubin (TB), it was found that the compound at a dose of $150 \mathrm{mg} / \mathrm{kg}$ has showed protective efficacy which is better than the protective efficacy showed by standard drug silymarin (value of aspartate 
amino transferase (compound) $=71.10 \pm 0.12$, (toxic) $=173.43 \pm 1.21$, (silymarin) $=79.86 \pm 0.02$ and total bilirubin (compound) $=1.04 \pm 0.11$ ), (toxic) $=2.69 \pm 0.02$, (silymarin) $==1.11 \pm 0.01$ ). The findings were also confirmed by histo-pathological observations.

Table 1: Protective efficacy of 2-3-6 trimethyloct-6-enal on biochemical parameters against paracetamol induced hepatotoxicity in swiss albino mice

\begin{tabular}{|c|c|c|c|c|c|c|c|}
\hline Sample & AST (U/l) & ALT (U/l) & ALP (U/l) & TB (mg/dl) & TGL (mg/dl) & TC (g/dl) & Protein $(\mathrm{mg} / 100 \mathrm{ml})$ \\
\hline Group I & $59.19 \pm 0.02$ & $52.36 \pm 0.21$ & $126.17 \pm 1.11$ & $0.53 \pm 0.09$ & $91.32 \pm 1.01$ & $65.03 \pm 0.12$ & $88.3 \pm 0.12$ \\
\hline Group II & $173.43 \pm 1.21^{\mathrm{a}}$ & $106.03 \pm 1.11^{\mathrm{a}}$ & $264.75 \pm 2.12^{\mathrm{a}}$ & $2.69 \pm 0.02^{\mathrm{a}}$ & $38.26 \pm 0.46^{\mathrm{a}}$ & $194.97 \pm 1.72^{\mathrm{a}}$ & $161 \pm 1.12^{\mathrm{a}}$ \\
\hline Group III & $79.86 \pm 0.02^{\mathrm{a}, \mathrm{e}}$ & $67.73 \pm 1.24^{\mathrm{b}, \mathrm{e}}$ & $170.39 \pm 0.35^{\mathrm{b}, \mathrm{e}}$ & $1.11 \pm 0.01^{\mathrm{a}, \mathrm{e}}$ & $54.15 \pm 0.59 \mathrm{~b}, \mathrm{e}$ & $93.23 \pm 0.12^{\mathrm{a}, \mathrm{e}}$ & $51.8 \pm 1.19^{\mathrm{a}, \mathrm{e}}$ \\
\hline Group IV & $79.18 \pm 0.01^{\mathrm{a}, \mathrm{e}}$ & $72.17 \pm 1.42^{\mathrm{a}, \mathrm{e}}$ & $221.10 \pm 0.47^{\mathrm{b}, \mathrm{e}}$ & $1.37 \pm 0.07^{\mathrm{a}, \mathrm{e}}$ & $62.47 \pm 0.32^{\mathrm{a}, \mathrm{e}}$ & $92.81 \pm 1.23$ & $62.46 \pm 2.12^{\mathrm{a}, \mathrm{e}}$ \\
\hline Group V & $71.10 \pm 0.12^{\mathrm{a}, \mathrm{d}, \mathrm{e}}$ & $79.21 \pm 0.54^{\mathrm{a}, \mathrm{d}, \mathrm{e}, \mathrm{g}}$ & $202.19 \pm 1.20^{\mathrm{a}, \mathrm{e}}$ & $1.04 \pm 0.11^{\mathrm{a}, \mathrm{e}, \mathrm{f}, \mathrm{g}}$ & $52.50 \pm 0.63^{\mathrm{a}, \mathrm{e}, \mathrm{g}}$ & $80.95 \pm 1.42^{\mathrm{a}, \mathrm{d}, \mathrm{g}}$ & $52.27 \pm 1.32^{\mathrm{a}}$ \\
\hline Group VI & $101.46 \pm 1.12$ & $85.46 \pm 1.02^{\mathrm{a}, \mathrm{e}, \mathrm{g}}$ & $197.22 \pm 1.49^{\mathrm{b}, \mathrm{e}, \mathrm{g}}$ & $0.90 \pm 1.12^{\mathrm{a}, \mathrm{e}}$ & $52.66 \pm 1.32^{\mathrm{a}, \mathrm{e}, \mathrm{g}}$ & $81.66 \pm 0.45^{a}$ & $58.07 \pm 1.17^{\mathrm{a}}$ \\
\hline
\end{tabular}

$\mathrm{n}=6$ animal, values are given as mean $\pm \mathrm{SE}$, values are statistically significant at $\mathrm{P}<0.001, \mathrm{P}<0.01$ and $\mathrm{P}<0.05$ level of significance. a-compared with control $\mathrm{P}<0.001$, b-compared with control $\mathrm{P}<0.01$,c-compared with control $\mathrm{P}<0.05$, d-compared with standard $\mathrm{P}<0.001$, e-compared with toxic $\mathrm{P}<0.001$. f-compared with standard $\mathrm{P}<0.01$, g-compared with standard $\mathrm{P}<0.001$. Group I-control, GroupII-toxic (paracetamol), Group III-standard (Silymarin), Group IV-50 mg/kg b.w. p. o. dose of 2-3-6 trimethyloct-6-enal; Group V-150 mg/kg b.w. p. o. dose of 2-3-6 trimethyloct-6-enal; GroupVI-250 mg/kg b.w. p. o. dose of 2-3-6 trimethyloct-6-enal.

\section{Measurement of antioxidant enzymatic and non-enzymatic levels}

Mice treated with a single dose of Paracetamol $(2 \mathrm{mg} / \mathrm{kg}$ body weight per orally) developed significant hepatic damage as observed from elevated levels of LPO $(4.02 \pm 0.01)$ and decreased levels of SOD $(0.29 \pm 0.02)$, CAT $(0.11 \pm 0.01), \quad$ GPx $(19.88 \pm 1.01)$, and GSH $(13.84 \pm 0.51)$ in hepatic cells. Pretreatment with $2,3,6$ trimethyloct6-enal at dose concentration of $50 \mathrm{mg} / \mathrm{kg}, 150 \mathrm{mg} / \mathrm{kg}$ and 250 $\mathrm{mg} / \mathrm{kg}$ b.w. p. o. conferred significant $(\mathrm{P}<0.001$ and $\mathrm{P}<0.01$ compared to control, $\mathrm{P}<0.001$ compared to toxic and $\mathrm{P}<0.01$ compared to standard) protection in antioxidant enzymatic and nonenzymatic levels of swiss albino mice by lowering the elevated levels of LPO and by increasing the decreased levels of SOD, CAT, GPx, and GSH. $150 \mathrm{mg} / \mathrm{kg}$ b.w. p. o. dose of 2,3,6 trimethyloct-6-enal exhibited a maximum level $(\mathrm{P}<0.001$ compared to toxic) of antioxidant activity [LPO $(0.92 \pm 0.01)$ and decreased levels of SOD $(0.79 \pm 0.01)$, CAT

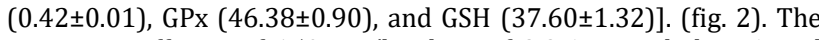
protective efficacy of $150 \mathrm{mg} / \mathrm{kg}$ dose of 2,3,6 trimethyloct-6-enal was similar to that of protective efficacy exhibited by standard drug Silymarin ( $50 \mathrm{mg} / \mathrm{kg}$ b.w. p. o.). The result was also supported by histopathological observations (fig. 3).

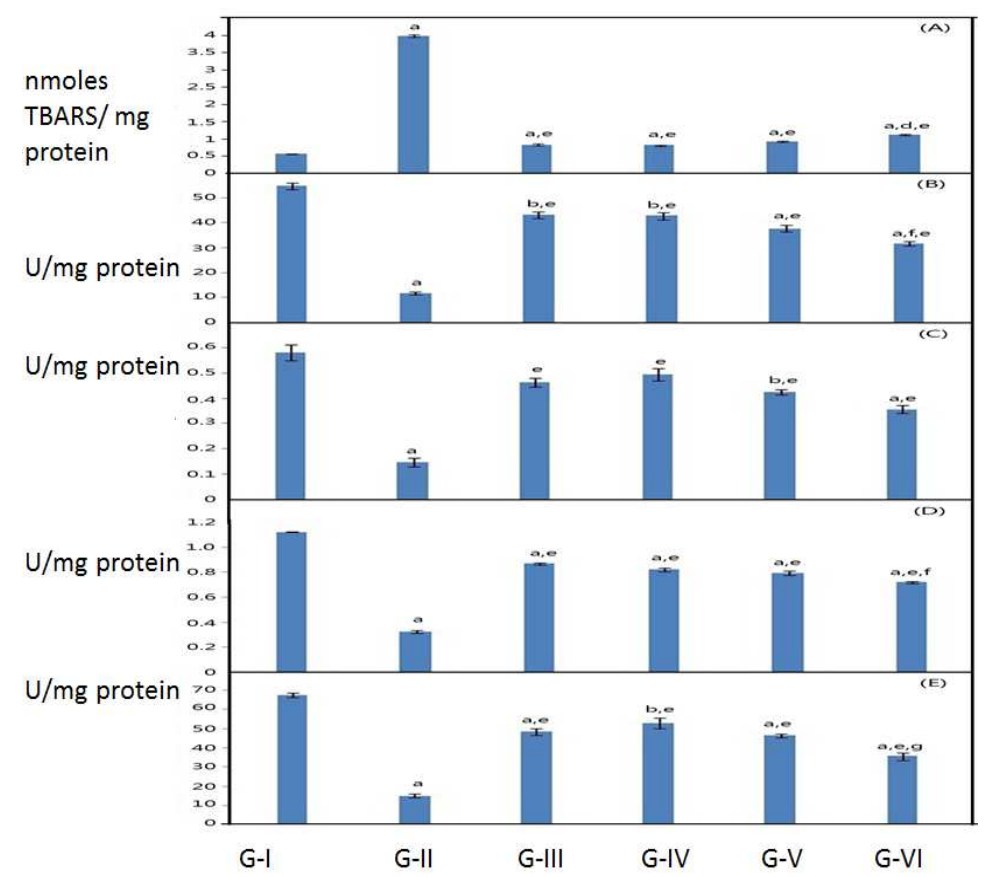

Fig. 2: Antioxidant efficacy offered by 2,3,6-trimethyloct-6-enal at different dose concentration manner on tissue enzymatic and nonenzymatic levels of Swiss albino mice against Paracetamol induced hepatic damage. (A) Changes in LPO level, (B) changes in GSH level, (C) changes in CAT level, (D) changes in SOD level, (E) changes in GPx level

a-compared with control $\mathrm{P}<0.001$, b-compared with control $\mathrm{P}<0.01$, c-compared with control $\mathrm{P}<0.05$, d-compared with standard $\mathrm{P}<0.001$, e-compared with toxic $\mathrm{P}<0.001$, f-compared with standard $\mathrm{P}<0.01$, g-compared with standard $\mathrm{P}<0.001$ Group I-control, GroupIItoxic (paracetamol), Group III-standard (Silymarin), Group IV-50 $\mathrm{mg} / \mathrm{kg}$ b.w. p. o. dose of 2,3,6-trimethyloct-6-enal; Group V-150 $\mathrm{mg} / \mathrm{kg}$ b.w. p. o. dose of 2,3,6-trimethyloct-6-enal; GroupVI-250 $\mathrm{mg} / \mathrm{kg}$ b.w. p. o. dose of 2,3,6-trimethyloct-6-enal.
Histopathological studies of the liver in paracetamol induced hepatotoxicity

Group I: Section studied shows normal hepatocytes with normal parenchyma and sinusoids.

Group II: Section studied shows liver parenchyma with effaced hepatocytes with macrosteatosis, and also some degenerative changes. 
Group III and V: Section studied shows liver parenchyma with the healing of necrosis. (table 2.)
Group IV and VI: Section studied shows liver parenchyma with partially healing of necrosis. (fig. 3)

Table 2: Histopathological changes in paracetamol induced liver injury in mice

\begin{tabular}{llllll}
\hline $\begin{array}{l}\text { Microscopic } \\
\text { Observation }\end{array}$ & Control & $\begin{array}{l}\text { Paracetamol } \\
\text { treated }\end{array}$ & $\begin{array}{l}\text { Compound 50 } \\
\mathbf{m g} / \mathbf{k g}\end{array}$ & $\begin{array}{l}\text { Compound 150 } \\
\mathbf{m g} / \mathbf{k g}\end{array}$ & $\begin{array}{l}\text { Compound 250 } \\
\mathbf{m g} / \mathbf{k g}\end{array}$ \\
\hline $\begin{array}{l}\text { Nuclear } \\
\text { disintegration }\end{array}$ & - & ++ & - & - & - \\
$\begin{array}{l}\text { Cytoplasmic } \\
\text { Vacuolation }\end{array}$ & - & ++ & + & - & - \\
Necrobiosis & - & + & - & - & - \\
Necrosis & - & +++ & - & - & - \\
$\begin{array}{l}\text { Kuppfercell } \\
\text { Hyparplasia }\end{array}$ & - & +++ & - & - & - \\
$\begin{array}{l}\text { Sinusoidal dialation } \\
\text { Centralvenous }\end{array}$ & - & - & ++ & - & - \\
Dialation & - & + & - & - \\
\end{tabular}
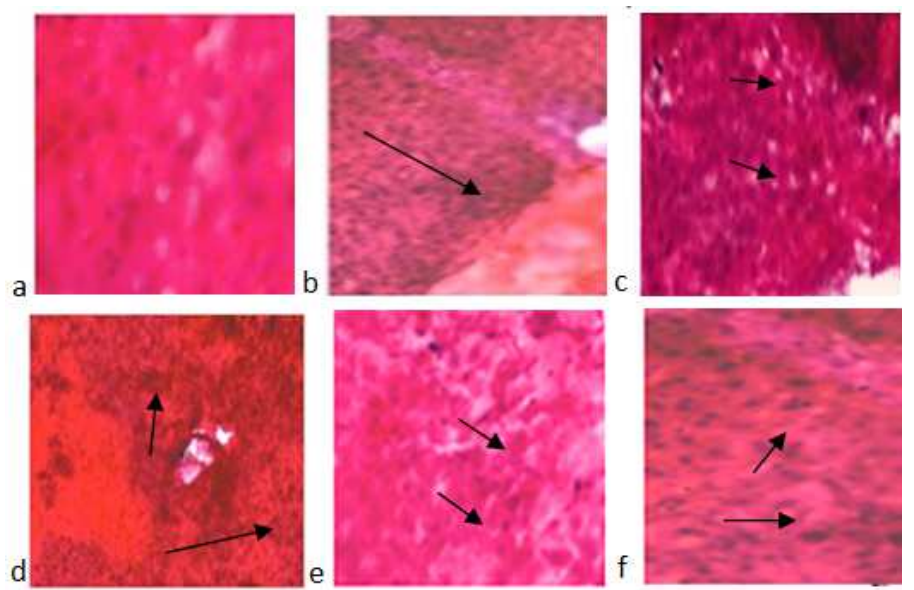

Fig. 3: Histopathological studies of sections of mice liver on $6^{\text {th }}$ day after treatment. (a) Control, (b) paracetamol (2 mg/kg b.w. p. o.),(c) Silymarin (50 mg/kg b.w. p. o.), (d) $50 \mathrm{mg} / \mathrm{kg}$ b.w. p. o. dose of 2-3-6 trimethyloct-6-enal, (e) $150 \mathrm{mg} / \mathrm{kg}$ b.w. p. o. dose of 2-3-6 trimethyloct-6-enal (f) $250 \mathrm{mg} / \mathrm{kg}$ b.w. p. o. dose of 2-3-6 trimethyloct-6-enal. In (b) arrow mark is the nacrosis and in (c), (d), (e), (f) arrow mark is the healing of nacrosis

\section{DISCUSSION}

Liver damage occured mainly cellular necrosis which associated with an increase in tissue LPO and depletion in the tissue GSH levels. In addition, hepatocellular injury can also measured by measuring the serum enzyme levels as because the hepatospecific enzymes are released in circulation and therefore it can be measured by measuring the serum enzyme levels. The hepatic cells consist of a higher concentration of AST and ALT in cytoplasm and AST particularly exists in mitochondria. High concentration of bilirubin in the serum is an indication for increased erythrocyte degeneration rate. On the other hand, ALP level in serum is related to the function of hepatic cells. Increased of ALP level in serum is due to increase synthesis in presence of increasing biliary pressure. A significant alteration in serum enzymes, bilirubin and tissue enzymatic, nonenzymatic levels were recorded after $6^{\text {th }}$ day of paracetamol intoxication, indicating considerable hepatocellular injury.

$\mathrm{N}$-acetyl p-benzoquinine amine (NAPQI) is a toxic electrophile which is activated by paracetamol induction and covalently interact with membrane molecule by losing one electron resulting membrane damage. This results into the leakage of biochemical markers into the serum [4]. Compound 2-3-6 trimethyloct-6-enal from the bark of the selected plantwere exhibited significant activity in dose dependent manner. The dose was selected by acute toxicity study. In a previous study, it was found that the compound 2-3-6 trimethyloct-6-enal has some oxidative stress reducing activity against $\mathrm{CCl}_{4}$ induced hepatotoxicity in mice. In this study, the compound exhibited subsequent recoverey in the levels of tissue enzymatic, non-enzymatic and serum biochemical parameters towards normalcy against paracetamol induced toxicity in mice. In histopathological observations, it was found that the compound exhibited similar and in some parameters better result than the protective activity exhibited by standard drug Silymarin.

\section{CONCLUSION}

It can be concluded that the compound 2-3-6 trimethyloct-6-enal from the methanol extract of Pajanelia longifolia (Willd.) K. Schuman has protective effects against paracetamol induced liver damage in mice as it ameliorates almost to normalcy the damage caused by paracetamol. Hence, this study suggests that the compound 2-3-6 trimethyloct-6-enal at a dose of (i.e. $150 \mathrm{mg} / \mathrm{kg}$ ) should be considered as an effective liver protective agent.

\section{ACKNOWLEDGEMENT}

The authors are grateful to the University Grant Commission for providing financial assistance in the form of UGC-AUS fellowship. Authors are thankful to Dr. Shuvasish Choudhury, CIL Assam University for necessary help and guide. Also, authors are thankful to Bioinformatics Centre, Assam University for e-journal access facilities.

\section{CONFLICT OF INTERESTS}

Declared none 


\section{REFERENCES}

1. Bhumika Y, Ashutosh M. Hepatoprotective effects of polyherbal formulation against carbon tetrachloride induced hepatic injury in albino rats: a toxicity screening approach. Asian J Pharm Clin Res 2017;10:192-5.

2. Gupta M, Majumder UK, Thamilselvan V, Manikandan, Senthilkumar GP, Suresh R, et al. Hepatoprotective effect and antioxidant role of methanol extract of oldenlandia umbellate in carbon tetrachloride induced hepatotoxicity in wistar rats. Iranian J Pharmacol Ther 2007;6:5-9.

3. Ajay K, Monika S, Prem PS, Sandeep KS, Pratima R, Kapil DP. Antioxidant efficacy and curcumin content of turmeric (curcuma-longa l.) flower. Int J Curr Pharm Res 2016;8:112-4.

4. Rajashekhar U, Vrushabendra Swamy BM, Jayaveera KN. Hepatoprotective activity of a hydro-alcoholic extract of the whole plant of Solanum dulcamara l. and Nephrolepis cordifolia (l) c. Presl against paracetamol induces hepatotoxicity in albino rats. Asian J Pharm Clin Res 2015;8:364-70.

5. Archana D, Dixitha M, Santhy KS. Antioxidant and anti clastogenic potential of piper longum l. Int J Appl Pharm 2015;7:11-4.

6. Yadav NP, Dixit VK. Hepatoprotective activity of leaves of Khalanchoe pinnata pers. J Ethnopharmacol 2003;86:197-202.

7. Datta S, Choudhury S, Choudhury MD. Hepatoprotective activity of bark of Pajanelia longifolia (Willd.) K. Schumann against $\mathrm{CCl}_{4}$ induced hepatic damage in mice. Drug Invention Today 2012;4:537-9.

8. Siddiqui A, Ali A. Prac pharm chem. $1^{\text {st }}$ ed. CSD publishers and distributors, 4596/1A, 11-Daryganj, New Delhi, India; 1997. p. 125-31.

9. Reitman S, Frankel AS. A colorimetric method for determination of serum glutamic oxaloacetic and glutamic pyruvic transaminase. Am J Clin Pathol 1957;28:56-63.

10. Malloy HR, Evelyn KA. The determination of bilirubin with the photoelectric colorimeter. J Biol Chem 1937;119:481.
11. Sood R. Medical laboratory Technology, methods and interpretation. $5^{\text {th }}$ ed. Jaypee Brothers Medical publishers Ltd.: New Delhi; 1999. p. 488-90.

12. Lowry $\mathrm{OH}$, Rosenbrough NJ, Farr AL, Randall RJ. Protein measurement with Folin's phenol reagent. J Biol Chem 1951;193:265-75.

13. Mohandas J, Marshal J, Duggin G, Horvath JS, Tiller D. Differential distribution of glutathione and glutathione related enzymes in rabbit Kidney. Cancer Res 1984;44:5086-91.

14. Pedraza Chaverri J, Barrera D, Medina-Campos ON, Carvajal RC, Fernandez-Pando R, Macias-Roval Caba NA. Time course study of oxidative and nitrosative stress and antioxidant enzymes in $\mathrm{K}_{2} \mathrm{Cr}_{2} \mathrm{O}_{7}$ inducad hepatotoxicity. BMC Nephrol 2005;6:4.

15. Dhindsa RH, Plumb Dhindsa P, Thorpe TA. Leaf senescence correlated with increased level of membrane permeability, lipid peroxidation and decreased the level of SOD and CAT. J Exp Bot 1981;32:93-101.

16. Ellman GL. Tissue sulphydryl groups. Arch Biochem Biophy 1959;82:70-7.

17. Lee SJ, Lim KT. Glycoprotein of Zanthoxylum piperitum Dc. has a hepatoprotective effect Via anti-oxidative character in vivo and in-vitro. Toxicol In Vitro 2008;22:376-85.

18. Jothy SL, Zakaria Z, Chen Y, Lau YL, Sasidharan S. Acute oral toxicity of methanolic extract of Cassia fistula in mice. Molecules 2011;16:5268-82.

19. Suparna Datta, Manabendra Dutta Choudhury. In vivo antioxidant activity of compound from the methanol extract of Pajanelia longifolia (Willd) K. Schuman. J Pharm Biol 2016;6:43-50.

\section{How to cite this article}

- Suparna Datta, Manabendra Dutta Choudhury. Antihepatotoxic potentiality of 2-3-6 trimethyloct-6-enal against paracetamol Induced liver dysfuntion. Int J Pharm Pharm Sci 2017;9(9):59-63. 